\title{
"Quem chegar por último é mulher do padre": as Cartas de Perdão de concubinas de padres na Baixa Idade Média portuguesa
}

\section{Edlene Oliveira Silva**}

\section{Resumo}

$\mathrm{Na}$ sociedade medieval portuguesa, a prática do concubinato clerical representou uma ameaça ao celibato e ao casamento religioso, instituições fundamentais para o projeto de ordenamento social defendido pela Igreja e pela monarquia. Nos séculos XIV e $\mathrm{XV}$, as leis civis definiram o concubinato clerical como um crime. No entanto, havia a possibilidade de absolvição ou diminuição da pena por meio das Cartas de Perdão, importante instrumento jurídico para compreender as representações de gênero que mediaram o olhar da justiça, forjando a imagem das concubinas como pecadoras e criminosas.

Palavras-chave: Celibato, Casamento, Concubinato Clerical, Relações de Gênero.

\footnotetext{
" Recebido para publicação em 19 de agosto de 2009, aceito em 08 de novembro de 2010.

** Professora Adjunta do Departamento de História da Universidade de Brasília. edlene@unb.br.
}

cadernos pagu (37), julho-dezembro de 2011:357-386. 
"Quem chegar por último émulher do padre"

"Last One There's the Priest's Wife":

The Letters of Pardon to Priests Concubines in Lower Portuguese

Middle Ages

\begin{abstract}
In the medieval Portuguese society, the practice of clerical concubinage represented a threat to celibacy and religious marriages. These were fundamental institutions to the social ordination project defended by the Church and the monarchy. In the fourteenth and fifteenth centuries the civil laws defined clerical concubinage as crime. However, there was the possibility of acquittal or sentence reduction by means of Letters of Pardon, an important legal tool to understand the gender representations that have mediated the eye of justice, forging the image of concubines as sinners and criminals.
\end{abstract}

Key Words: Celibacy, Marriage, Clerical Concubinage, Gender Relations. 
Em Portugal, nos séculos XIV e XV, a palavra comumente utilizada para se referir à concubina era barregã. No livro $V$ das Ordenações Afonsinas ${ }^{1}$, que trata das práticas qualificadas como criminosas, bem como suas respectivas penalidades, existe uma grande quantidade de interdições às barregãs. As Ordenações Afonsinas consignavam três modalidades de barregania (concubinato): a com homens solteiros, a com homens casados $e$ a com homens religiosos. Neste artigo trataremos especificamente das barregãs de clérigos, definidas pela legislação como mulheres que viviam em "pecado público" com religiosos em sua casa de morada ou que deles dependiam materialmente para se alimentar e vestir (Ordenações Afonsinas, artigo 5:61). Em contraposição à mulher casada vista como honrada e honesta, a barregã de clérigo era classificada como praticante de um pecado mortal que ameaçava a ordem do Reino e a salvação da alma de todos os cristãos.

Ao serem acusadas e/ou condenadas pela justiça régia, as barregãs de clérigos podiam recorrer às Cartas de Perdão, documentos judiciais pelos quais o monarca outorgava perdão a um ou mais súditos, na sequência de um crime. A concessão do perdão podia suspender a execução de uma sentença, liberando o réu de toda a pena, de parte dela ou comutando-a por uma punição mais leve. Na sociedade portuguesa dos séculos XIV e XV, o perdão era um ato exclusivo do rei.

A análise das Cartas de Perdão escritas por barregãs de clérigos permite aprofundar a investigação acerca do imaginário medieval português, sobretudo as representações de gênero que orientaram as formulações do discurso jurídico a respeito do desvio feminino. Pela voz das narradoras tive acesso às imagens que as mulheres acusadas ou condenadas pelo pecado/crime $e^{2} \mathrm{de}$

\footnotetext{
${ }^{1}$ Código jurídico luso de 1446, composto de cinco livros que reúnem leis de diferentes reinados.

2 Aqui utilizados como termos sinônimos devido as íntimas relações entre Monarquia e Igreja na Idade Média.
} 
"Quem chegar por último émulher do padre"

barregania clerical construíram sobre elas mesmas, com o intuito de se defender perante o rei das acusações que lhes foram imputadas.

As Cartas evidenciam que a justiça atribuía a responsabilidade pela prática da barregania, principalmente às mulheres, com base na ideia de uma natureza feminina sensual e perversa. A interpretação cristã do Gênesis culpa Eva pelas desgraças humanas, impingindo-lhe como castigo a submissão do seu destino à vontade do marido, em conformidade com a mentalidade patriarcal do período. No crime de barregania clerical, a culpabilidade de Eva legitimava que as mulheres fossem condenadas a uma punição mais rigorosa que os homens. Como Adão, os religiosos eram vítimas da luxúria e da sedução das barregãs. O olhar jurídico reforçava a representação cristã de que os desvios sexuais eram usualmente causados pelas mulheres. Portanto, era preciso vigiá-las e, se necessário, puni-las para que se conformassem aos modelos da mulher honesta. Apesar da tradição medieval quase não conferir autonomia jurídica às mulheres (que geralmente não podiam assinar contratos, doações ou testamento sem o consentimento do tutor por sua "insuficiente razão"), a suposta debilidade inerente à natureza feminina tanto podia servir como argumento para uma redução da pena, quanto para o aumento da mesma. A falta de firmeza feminina perante o pecado $e$ as tentações demoníacas muitas vezes justificavam condenações severas.

As penalidades estipuladas para o pecado/crime de barregania variavam de acordo com as circunstâncias e o estamento social, a religião e a idade dos envolvidos na transgressão, entre outros critérios. $\mathrm{O}$ fato de uma mulher ser barregã de clérigo era um agravante para uma justiça informada por valores religiosos. São Tomás de Aquino afirmava que a gravidade do pecado alterava-se segundo a condição da pessoa ofendida: "o pecado resulta mais grave pelo fato de se pecar contra uma pessoa unida a Deus por razão da virtude ou por razão do seu oficio" (Tomás de Aquino, 1989:582). 
Cabe ressaltar que a perseguição às barregãs se insere no contexto da Reforma Gregoriana - compreendida como um extenso movimento de reformulação moral da Igreja e da sociedade ocorrido no século XII. Durante o I Concílio de Latrão (1123), foi estabelecida a proibição do casamento $e$ do concubinato a todo o clero latino. A instituição do celibato clerical foi fundamentada na associação entre pureza e castidade que irá balizar todo o discurso de autoridade da Igreja perante os leigos e representantes de outras religiões nas quais era permitido o matrimônio de sacerdotes. Latrão (apud Almeida, 1967:234) determinou não apenas a proibição das relações de concubinato, mas a anulação dos casamentos de clérigos:

\begin{abstract}
Proibimos totalmente aos presbíteros, diáconos, subdiáconos e monges de ter concubinas ou contrair casamentos. Decidimos também que os casamentos de tais pessoas sejam dissolvidos $e$ as pessoas submetidas a penitências de acordo com o grau do sacramento recebido.
\end{abstract}

As esposas e concubinas de clérigos passaram a ser consideradas adúlteras e prostitutas pela Igreja, vistas como um entrave para o projeto de controle social eclesiástico que, dentre outros objetivos, pretendia santificar a conduta dos religiosos. A Reforma Gregoriana foi fundamental na percepção de que o concubinato e o casamento clerical eram um grande perigo que afetava todos os setores da Igreja.

Seguindo os preceitos reformistas, após a ordenação, os padres deveriam permanecer castos. As mulheres deveriam optar por uma condição que assegurasse indubitavelmente a sua honra: a solteirice, a vida religiosa, o casamento ou a viuvez. Somente no casamento abençoado pela Igreja, único modelo legítimo de união marital, homem $e$ mulher podiam manter relações sexuais $e$ constituir uma família. O matrimônio de laicos era um estado superior, pois o homem e a mulher solteiros estavam constantemente ameaçados pelos arroubos da libido, o que 
"Quem chegar por último émulher do padre"

dificultava a disciplina do corpo. Mas, para os clérigos, o enlace conjugal era interditado. $\mathrm{O}$ celibato convertera-se em essência da identidade eclesiástica.

A barregania clerical pode ser vista como um ato de insurgência contra o celibato e o casamento, daí a sua veemente perseguição pelo poder régio e pela Igreja. Desafiando os papéis definidos para atuação do feminino, tais mulheres foram responsabilizadas por desvirtuar clérigos e gerar filhos bastardos, maculando duas instituições basilares para ordenamento da sociedade medieval: o sacerdócio e a família (núcleo do patriarcado). Nesse sentido, o estudo das identidades de gênero é fundamental para contextualizar o lugar de fala "subalterno" das barregãs, uma vez que o gênero é

um elemento constitutivo das relações sociais, baseadas nas diferenças percebidas entre os sexos e mais, o gênero é uma forma primeira de dar significado às relações de poder (Scott, 1994:13).

Portanto, ser barregã ultrapassou as fronteiras da moral religiosa representada pela noção de pecado - e passou a ser tipificado como um grave crime.

\section{Os pedidos de clemência: entre táticas de consentimento e a incorporação da dominação do feminino na Idade Média}

As Cartas de Perdão são as principais vozes das barregãs de clérigos, contudo apresentam a fala feminina na forma de um discurso conformado pelas intermediações masculinas características do processo jurídico medieval. Os pedidos de remissão eram um entrecruzar de vozes: a do requerente, a do advogado conselheiro e a do tabelião. A requerente (no caso, a barregã ou um representante) narrava a história e o tabelião a redigia. Eventualmente, um advogado orientava a ré. $\mathrm{O}$ tabelião também podia assistir a requerente. Advogado $e$ tabelião colaboravam na confecção da narrativa, adequando o seu 
conteúdo e a sua forma ao objetivo da petição: convencer o rei de que a acusada merecia o perdão.

A intermediação masculina no discurso da barregã nos revela como "a construção da identidade feminina tem-se enraizado na interiorização pelas mulheres de normas enunciadas pelos discursos masculinos" (Chartier, 1994:09). A própria narrativa das Cartas de Perdão caracterizava-se por seguir uma estrutura linear e pela tentativa da organização coerente da história, de acordo com os parâmetros da racionalidade jurídica da época, forjada pelo discurso masculino.

[Para uma narrativa histórica, como a de uma Carta de Perdão] é necessário haver escolhas formativas de linguagem, detalhes e ordem para apresentar um relato que pareça verdadeiro, real, significativo e/ou explicativo, tanto para o autor como para o leitor. (...) as cartas de remissão eram um gênero misto: uma petição judicial destinada a persuadir o rei e a corte, um relato histórico dos atos de um indivíduo no passado e uma história (Davis, 2001:17).

As Cartas eram escritas logo após a prisão ou depois que a condenada havia cumprido uma parte da pena. Não obstante, algumas eram elaboradas antes que a acusada fosse presa, ou depois da sentença ser proferida. Tais documentos possuem muitas informações sobre os processos judiciários, do ato da denúncia à possível reabilitação. No entanto, para o reino português, os registros de Cartas de concubinas de padres datadas dos séculos XIV e XV são escassos. Dentre as mil e cinco Cartas de Perdão inventariadas por Luís Miguel Duarte, relativas ao período, apenas trinta e cinco foram escritas para a defesa de barregãs de clérigos. Como o autor, por opção metodológica, estudou apenas os crimes civis, a pesquisa não precisa quantas concubinas de religiosos receberam o perdão real (Duarte, 1993:330).

O custo elevado da Carta tendia a restringir o acesso ao perdão aos membros mais abastados do corpo social; entretanto, não consistia em um obstáculo incontornável. $\mathrm{O}$ poder régio não 
era insensível à extrema penúria. Quando a requerente era muito pobre, havia a possibilidade de que as taxas fossem reduzidas ou de que a Carta fosse concedida gratuitamente. Na França, por exemplo, estima-se que, no século XVI, $1 \%$ das Cartas de Perdão não era custeada pelo requerente (Davis, 2001:40). Em relação a Portugal, não há estudos que informem números sobre o assunto.

As Cartas que analisei não apontam a condição social das mulheres acusadas ou condenadas por barregania clerical (com exceção de uma, cujo requerente era um escudeiro real que solicitou ao rei clemência para a ama de leite do seu filho). Contudo, é possível inferir que as barregãs que solicitaram remissão nas outras Cartas investigadas não pertenciam à nobreza, pois a descrição do trabalho que executavam ou da situação em que se encontravam indica que desempenhavam atividades não condizentes com a condição nobiliárquica. No entanto, deve-se ressaltar que o sistema penal tendia a reproduzir a hierarquização social, punindo os extratos menos favorecidos da sociedade. A condição econômica era um fator relevante que perpassava a categoria de gênero. $\mathrm{Na}$ sociedade medieval, um abismo separava o fidalgo do camponês; contudo, uma mulher nobre detinha mais direitos e privilégios que um homem camponês (Nascimento, 1997:90).

As Cartas estavam divididas em duas seções. Na primeira parte, era escrito o relato da barregã iniciado com o vocativo ao rei e aos juízes do Reino. Logo após, declarava-se o nome da requerente, o seu local de residência e, às vezes, a sua profissão e, depois, narrava-se a história da acusada ou condenada: "Maria Gonçalves, moradora de Lisboa, nos enviou dizer que (...)". Seguiam-se informações sobre as primeiras medidas tomadas pela justiça, a maneira como foi presa e o período em que permaneceu em detenção. Ao final do relato, a ré solicitava a graça real, na terceira pessoa: "Maria Gonçalves pediu-nos, por mercê e honra da morte e paixão de Nosso Senhor Jesus Cristo, que lhes perdoássemos a nossa justiça por razão do que nos é dito (...)". $\mathrm{Na}$ segunda parte, era registrado o despacho régio. Havia a 
possibilidade de que o rei concedesse o perdão, indeferisse o pedido ou ainda solicitasse mais informações acerca do caso.

A Carta de Maria Gonçalves, moradora de Lisboa, narra a história de como foi condenada por concubinato clerical. A trama se inicia com a prisão de Gonçalves por oficiais régios, sob a acusação de que ela tinha "afeição com um clérigo". No cárcere, onde permaneceu por um período de cinco meses, ela teve, junto ao "tormento e nojo" da prisão, uma criança (provavelmente, filha do clérigo do qual ela fora concubina). Após o parto, foi condenada ao degredo, por um ano, de Lisboa e do seu termo. (Liuro de Chancelaria de D. Duarte, vol. 3, fl. 19v). Na lógica jurídica do medievo, quanto mais grave o crime, mais longe era o local do degredo em relação à cidade onde o delito fora cometido. $\mathrm{Na}$ maioria das Cartas analisadas, as barregãs de clérigos foram condenadas a cumprirem, no mínimo, um ano de exílio nas áreas do reino português destinadas ao degredo. Muitas ficavam reclusas em prisões lusas, por meses, antes de serem enviadas para seu local de destino como foi o caso de Maria Gonçalves. Ao término da narrativa, segue-se a exposição dos motivos destinados a sensibilizar o rei e garantir a misericórdia. Gonçalves justificava as razões de seu comportamento desviante e apresentava os argumentos para o merecimento do perdão régio. Como o monarca era o destinatário das Cartas, ele atuava como figura referencial para a estruturação do discurso. Ao redigir a Carta e recorrer às instâncias reais, a acusada afirmava a supremacia da política régia pela submissão aos valores sancionados como lícitos $e$ pelo arrependimento do crime cometido. A narrativa devia convencer $\mathrm{o}$ rei de que a requerente regenerara-se e não representava mais uma ameaça à ordem social.

Gonçalves apresentou a fragilidade da natureza humana como a principal justificativa para a sua falta: "o destino dos homens e das mulheres era pecar". Seu discurso se apropriava de uma imagem recorrente no imaginário medieval: a da natureza humana em estado de constante tentação demoníaca, facilmente corrompida pelo mal. Dessa forma, a requerente deslocava sua 
"Quem chegar por último émulher do padre"

responsabilidade pelo desvio, transferindo o foco da culpa para a natureza humana, mais forte do que sua vontade. Seu discurso introjeta e legitima uma relação de dominação inscrevendo-a em uma natureza inata que é, por sua vez, ela própria uma construção social naturalizada.

$\mathrm{O}$ discurso de Gonçalves não contestou diretamente as representações de gênero dominantes na sociedade. É possível que a acusada tenha forjado sua defesa como uma forma de resistência denominada por Roger Chartier de "tática do consentimento" (1995:42) empregada por mulheres que invertem as imagens que lhe são atribuídas pelas representações de gênero com intuito de não serem excluídas de alguma situação ou meio. Dessa maneira, Maria Gonçalves poderia ter tentado desconstruir o estigma da pecadora assumindo o papel da vítima arrependida para tentar obter o perdão real. Por outro lado, Gonçalves poderia ter introjetado à dominação masculina e ter expressado real arrependimento e desejo de corrigir-se. Ou, ainda, que simplesmente fazia o que tinha que ser feito, dentro dos padrões da época, para se tentar libertar da difícil situação em que encontrava.

Nem todas as fissuras que corroem as formas de dominação masculina tomam a forma de dilacerações espetaculares, nem se exprimem sempre pela irrupção singular de um discurso de recusa ou de rejeição. Elas nascem com frequência no interior do próprio consentimento, quando a incorporação da linguagem da dominação se encontra reempregada para marcar uma resistência (Chartier, 1995:42).

No entanto, em outro momento da sua carta, essa atitude de aparente submissão assume uma posição de tensão, ou mesmo de confronto aos valores instituídos pelo discurso jurídico. Gonçalves solicitava a comutação da pena de degredo com a declaração de que já havia sofrido o suficiente para expiar a culpa. Asseverava que estava preparada para retornar à sociedade e que 
viveria em conformidade com as regras estabelecidas, mas ao mesmo tempo, deixava claro que suas penas eram severas demais para o pequeno dano que acreditava causar à sociedade. A sua história foi narrada com intensa dramaticidade: "a prisão, tribulação e custa de tudo e o perdimento da dita criatura [seu filho], durante o parto, foram e eram muitas grandes penas sob tão pequena culpa".

O relato da via-crúcis da barregã, encarcerada e condenada ao degredo, destinava-se a persuadir o monarca de que ela sofrera provações indispensáveis ao cumprimento da penitência, que já estava purificada do pecado/crime de barregania clerical e, portanto, merecia o perdão régio. A prática do degredo conformava-se a concepção de mundo cristã que estabelecia para os criminosos a necessidade de que purificassem suas almas. $\mathrm{O}$ cumprimento do exílio equivalia a uma estada no purgatório: o condenado, que representava um perigo à ordem do Reino, era castigado com o banimento da sociedade e enviado a uma região compreendida como um local de redenção dos pecados (Le Goff, 1979:43-60). O pensamento jurídico medieval era informado pelo relato mítico da criação que associava pecado original à expulsão do Paraíso: havia uma correspondência entre o pecado/crime cometido e a penitência/penalidade judicial. Na interpretação cristã do Gênesis, o sofrimento era uma penitência e a finalidade da punição possibilitava ao condenado a expiação do pecado e a reconciliação com Deus, pois o homem decaído manifestava grandes dificuldades para ajustar os seus atos aos mandamentos da lei divina.

Seguindo a interpretação do Gênesis de Santo Agostinho, se Eva não tivesse seduzido Adão a incorrer no pecado de concupiscência, os seres permaneceriam perfeitos (à semelhança de Deus), destinados a viver em eterna harmonia, privados das doenças, da velhice e da morte. A imensa gravidade do pecado original provocado pelos ardis femininos demandou um castigo correspondente que afetou toda a humanidade, condenada a enfrentar padecimentos físicos e espirituais. 
"Quem chegar por último émulher do padre"

Este sexo envenenou o nosso primeiro pai, que era também o seu marido e pai, estrangulou João Batista, entregou o corajoso Sansão à morte. De certa maneira, também, matou o Salvador, por que, se a sua falta o não tivesse exigido, o nosso Salvador não teria tido necessidade de morrer. Esgraçado sexo em que não há nem temor, nem bondade, nem amizade e que é mais de temer quando é amado do que quando é odiado (Dalarum, 1993:34-38).

Após assegurar que estava regenerada, Maria Gonçalves solicitou perdão ao rei e suplicou que pudesse "viver de forma honesta onde desejasse". Dificilmente o rei teria atendido ao pedido final. A legislação lusa da baixa Idade Média proibia que as concubinas condenadas ao degredo, ao término do cumprimento da pena, tornassem a viver no mesmo local onde residisse o clérigo barregueiro. Os juízes que fossem negligentes na aplicação dessa norma corriam o risco de sofrer graves punições:

Mandamos que as mulheres que assim forem degradadas, depois que o forem, não morem mais nas freguesias onde morarem seus barregãos. E para isso melhor guardar mandamos que os juízes das cidades, vilas e lugares que a cada mês inquiram e saibam em seus julgados se há tais mulheres e façam a execução por escrito e estejam certos que se não o fizerem que lhe entranharemos nos corpos $e$ averes como nossa mercê for (Ordenações Afonsinas, livro V, artigo 11:63-64).

A promessa de reabilitação era um elemento indispensável à estrutura discursiva das Cartas de Perdão. O rei precisava ser convencido de que o pecado fora purgado e de que a ré pretendia "viver honestamente", optando por um dos estilos de vida sancionados pelas normas jurídicas: "casar ou entrar em ordem religiosa". A virgem, a mulher religiosa, a esposa e a viúva representavam os modelos de conduta feminina legitimados pela Igreja e pelo poder régio. As mulheres que se conformavam a 
esses padrões comportamentais eram valorizadas $e$ protegidas juridicamente, enquanto as que se desviavam eram consideradas desonestas e desprezíveis. A honestidade operava como um critério de seletividade que determinava, nos julgamentos, quais mulheres mereciam a proteção do sistema jurídico e quais eram criminosas e deveriam ser punidas.

A afirmativa de arrependimento pelo ato pecaminoso/ criminoso também constituía um elemento central das Cartas de Perdão. O rei, na condição de supremo guardião secular dos valores cristãos, esperava que o pecador/criminoso manifestasse contrição sincera. Para o monarca e a Igreja era preferível que o ser humano corrigisse os seus atos, do contrário tais poderes estabelecidos seriam obrigados a condenar todos os indivíduos que incorressem em transgressões graves - medida que criaria problemas para um mundo tão rarefeito como o medievo. $\mathrm{O}$ arrependimento público da má conduta era um exemplo para os membros da comunidade, que deveriam empenhar-se na busca incessante pela salvação, pela obediência à ordem e aos padrões sociais. $\mathrm{O}$ arrependimento marcava o momento de reintegração à sociedade do indivíduo que estivera situado à margem, propiciava a expiação da culpa e reparava a ofensa cometida contra a comunidade, o rei e a Deus. A negação do mesmo atentava contra o plano de ordenamento social, significando o triunfo do demônio, a perda de uma alma para o mal e a desordem. $\mathrm{O}$ discurso de Gonçalves provocou o efeito desejado: D. Duarte concedeu-lhe o perdão régio, em 6 de novembro de 1434.

Em 30 de abril de 1433, D. Afonso V, concedeu perdão a Beatriz Gonçalves, moradora de Santarém, acusada de ser concubina de clérigo (Livro de Chancelaria de D. Afonso V, vol. 27, fl. 101). A Carta de Perdão justificava que a ré cometera o crime porque fora vítima de mau conselho. No documento ela conta que foi aliciada por mulheres alcoviteiras que a convenceram a viver com um clérigo alegando que ele lhe arranjaria um matrimônio, como havia procedido com outras de suas mulheres. A assertiva de que a acusada fora vítima de mau conselho era um argumento 
"Quem chegar por último émulher do padre"

retórico muito utilizado nas Cartas de Perdão (Duarte, 1993:43). Beatriz havia sido induzida ao concubinato pela figura das alcoviteiras, que instigavam mulheres a cometerem transgressões, especialmente as de natureza sexual. Alcoviteira era aquela que tratava de assuntos da alcova (sinônimo de quarto íntimo), sendo sua imagem muito próxima a da cafetina. Também era versada nos assuntos da magia, como uma espécie de feiticeira que lançava mão de encantamentos e todo tipo de artimanhas inescrupulosas para desvirtuar pessoas em troca de pagamento.

O exercício desta atividade exige destas mulheres, além do domínio da bruxaria, da arte de mentir, de enganar e de roubar; enfim, de envolver as pessoas: às moças, prometendo-lhes mil coisas para transformá-las em prostitutas; aos homens, para que eles se encantem com os atrativos das moças e possam ser bem liberais com as alcoviteiras, dando-lhes dinheiro, presentes, bens de valor (Pitillo, 2002:81).

De uma forma geral, a mulher do medievo não tinha direito à voz e quando falava estava comumente associada ao discurso maldoso e maligno. Conquanto as Ordenações Afonsinas não definissem a alcovitagem como uma prática exclusivamente feminina (Livro V, título XVI, artigo 1:52), ela estava associada, sobretudo às mulheres (Rossiaud, 1991:39).

Os/as alcoviteiros/as eram personagens depreciados pela legislação real. Para as Ordenações Afonsinas, alcovitar era um ato "contra a vontade de Deus e contra a comunidade", causador de "males, mortes e homizios", pelo qual "mulheres inocentes $e$ honestas eram enganadas por essas pessoas a seguirem o caminho do pecado" (Livro V, artigo 1:52). As Ordenações Afonsinas determinavam a pena de morte como punição pelo crime de alcovitagem.

Nas Cartas de Perdão, as constantes referências ao mau conselho se destinavam a construir uma imagem favorável da ré o que não exclui a possibilidade de que ela se compreendesse 
como vítima de aliciamento. O relato de Beatriz apresentava uma imagem torpe do clérigo barregueiro como tentativa de imputar a culpa ao padre por meio de sua desqualificação moral e social. $\mathrm{O}$ religioso era descrito como um mau sacerdote que persistia na transgressão (ele era acusado de ter tido relações de concubinato com muitas mulheres). Beatriz, ao contrário, era uma pessoa que não pecara por iniciativa própria, mas que fora induzida ao erro por alcoviteiras que obedeciam ao clérigo. $\mathrm{O}$ depoimento procurava convencer o destinatário que a vida desviante de Beatriz não dependera da sua vontade: o discurso construiu a requerente como uma vítima incapaz de resistir ao terrível assédio das alcoviteiras e de desejar se casar para ser reconhecida socialmente.

A ideia de que a mulher era mais suscetível ao aliciamento $e$ naturalmente mais inclinada ao pecado assentava-se em matrizes discursivas e imagéticas bíblicas. No Gênesis, a alcovitagem é inferida no relato da Criação. Eva fora induzida a praticar o mal pela serpente - o animal astuto, a grande alcoviteira. Quando interrogada por Deus sobre por que havia comido o fruto proibido, Eva respondeu: "a serpente me seduziu" (cap. 3, vers. 13.). Ao argumentar que fora prejudicada por maus conselhos, Beatriz apropriava e reforçava a concepção da mulher como mais propensa que o homem às tentações. Eva, e não Adão, fora a vítima do estratagema da serpente.

Vale lembrar que a serpente arquetipicamente pode ser associada à imagem feminina de Lilith, o demônio em forma de mulher. Nos antigos livros hebraicos do Talmud e do Zohar, Lilith teria sido a primeira esposa de Adão que o abandonou após ser proibida de praticar relações sexuais "por cima". Então Deus viu a necessidade de criar Eva, uma nova companheira para Adão. Todavia, mesmo sendo feita das costelas de Adão (condição primordial de submissão), Eva também desafia Deus e o marido ao ser seduzida pelos ardis da serpente (estimulada pela vingativa Lilith). Nesse sentido, as duas mulheres primordiais são agentes 
"Quem chegar por último émulher do padre"

demoníacos responsáveis pela condição mortal e sofredora da humanidade.

O texto bíblico relata a dupla desobediência da mulher: Lilth não atende a convocação do Senhor para voltar para Adão; Eva come do fruto proibido e convence Adão a fazer o mesmo. O pecado original transforma os seres puros, criados por Deus, em seres impuros. A mulher, a principal responsável pela queda, expressa a sua impureza (...) Estruturalmente, Lilith e Eva cometeram o mesmo crime, o da desobediência ao Senhor e foram punidas da mesma forma: Todos os dias, por toda a eternidade, Lilith, "a mãe dos demônios" tem que se conformar com a morte de 100 lilim; da mesma forma, Eva é a responsável pela morte de todos os seus descendentes que poderiam ser imortais se continuassem a viver no Paraíso (Laraia, 1997:158).

Em termos míticos, a grande desobediência de Eva foi experimentar o prazer sexual e tomar para si "as dores do parto" carregando o dom da procriação e da maternidade, pois se não tivesse copulado com Adão todos os seres seriam imortais $e$ gerados pela graça divina, sem a intermediação humana.

As barregãs de clérigos eram tão temidas exatamente por induzirem os religiosos à queda e à paternidade, deslocando-os do status divinizante de sacerdotes castos para fazer deles homens comuns como Adão. A ousadia das barregãs está exatamente em unir em uma só identidade dois papéis rigidamente separados após a Reforma Gregoriana: o de maridos e sacerdotes.

No depoimento, Beatriz afirmava que incorrera em pecado porque desejava casar-se. $\mathrm{O}$ crime cometido era justificado com a alegação de que ela errara porque aspirava a uma condição social honrada e que nunca desejou ser barregã: "quando já tencionava abandonar o clérigo, as justiças a prenderam em uma rua não sendo achada com ele", e depois "foi condenada e degredada para fora da dita vila de Santarém e de seu termo por um ano". 
$\mathrm{O}$ relato nos informa que Beatriz pretendia abandonar a vida ilícita e que havia sido presa irregularmente, pois no momento da detenção ela não se encontrava na companhia do clérigo ou na residência paroquial. Tal dado demonstra como as mulheres, na prática, estavam suscetíveis de serem detidas sem a necessidade de provas concretas, apesar da legislação determinar o contrário. As Ordenações Afonsinas consignavam o seguinte:

E porque era dúvida quando alguma mulher era tomada $e$ presa fora da casa do dito clérigo, indo a fonte ou a outra parte. Mandamos que os Alcaides não as prendam, salvo quando forem achadas na casa do dito clérigo ou em outra residência suspeita. E façam isto quando souberem por testemunhas certas ou por tais indícios que pareçam prova. (Livro V, título XIX, artigo 17, p. 66).

A perspicácia dos argumentos expostos na Carta revela que Beatriz conhecia muito bem a legislação do Reino, ou fora instruída pelo tabelião ou por um advogado conselheiro. Após afirmar que cumprira a pena de degredo por um ano e que durante o cumprimento da punição "não tornou mais ao dito pecado nem a qualquer outro", ela solicitou o perdão ao rei, "em honra, morte e paixão de Nosso Senhor Jesus Cristo".

Deus e Jesus eram referências míticas sempre presentes nas Cartas de Perdão (Duarte, 1993:42). A fórmula "em honra, morte e paixão de Nosso Senhor Jesus Cristo", que encerrava o relato do requerente nas cartas de remissão, recordava que o rei, na condição de cristão e representante de Deus na terra, devia perdoar o criminoso, como Cristo perdoara os ladrões crucificados ao Seu lado na Sexta-Feira da Paixão. O ritual do perdão era uma representação mimética pela qual o rei atualizava o gesto de Jesus.

A penalidade podia ser amenizada ou suspensa significando um gesto magnânimo da comiseração real. No plano secular, o príncipe cristão era associado à imagem de Jesus e representado como um disciplinador manso e misericordioso. A mão que 
"Quem chegar por último émulher do padre"

ameaçava com castigos impiedosos também era pródiga na concessão da graça. Ao entrelaçar a ameaça e clemência, o rei assumia a dupla face da divindade: Pai justiceiro, Filho misericordioso. Os súditos submetiam-se ao monarca, pai e bom pastor, pelos laços do amor, mas também do terror (Hespanha, 1992:249).

A relação dialógica entre a permanência da ameaça $e$ a possibilidade do perdão atendia às necessidades de um sistema judiciário e penal que não possuía os recursos para efetivar a punição integralmente. Sobretudo, foi construída e conformada pelos valores religiosos defendidos pela Igreja, refletindo as relações análogas que se estabeleciam entre o pecado $e$ a clemência (Duarte, 1993:36). Beatriz recebeu o perdão régio e teve a pena de degredo comutada pelo pagamento de uma multa.

Em 28 de janeiro de 1444, D. Afonso V concedeu graça a Leonor Domingues Peixoto, moradora de Santarém, que trabalhava em um mosteiro dominicano como enfermeira dos religiosos doentes (Livro de Chancelaria de D. Afonso V, vol. 24, fl. 35v-36). Na Carta de Leonor, ela conta que para assistir um frade adoentado precisou dormir por algumas noites no mosteiro: "com que ela em sendo manceba foi afamada e curara dele como dos outros dormindo ela algumas noites no dito mosteiro". Um funcionário régio, informado do fato, denunciou Leonor como barregã de clérigo e ela foi condenada ao degredo. Na sociedade medieval portuguesa, qualquer pessoa podia delatar uma barregã em troca de dinheiro: "outorgamos que qualquer um do Povo possa acusar tais mulheres e receber a terça parte das penas" (Ordenações Afonsinas, livro V, título XIX, artigo 9:66). Não obstante, a acusação era geralmente apresentada pelos oficiais régios, que estavam encarregados de denunciar os casos de barregania clerical (Ordenações Afonsinas, livro V, título XIX, artigo 13, pp.64-65).

Leonor defendeu-se afirmando que a acusação era infundada: ela trabalhava honestamente no mosteiro e tinha sessenta anos de idade (e o frade acusado mais de setenta), portanto não era possível "que fizesse tal pecado por bem da dita 
idade". A idade do réu era uma informação significativa em um julgamento medieval. Nas Cartas de Perdão, a idade do requerente era usada na construção argumentativa da sua defesa. Alguns condenados apresentavam-se como "moços de pouco entender" (Duarte, 1993:43), imputando o crime cometido à ingenuidade juvenil. Leonor informou a idade avançada para persuadir o rei que the era impossível ter mantido relações concubinárias com o frade.

Outro apelo do discurso defensivo de Leonor foi a exaltação de sua condição de trabalhadora honesta, dedicada a um ofício valorizado e honrado. A atribuição de um estatuto socialmente respeitável era um dos recursos mais eficazes em defesa da ré. Inocentada das acusações e perdoada pelo rei, Leonor obteve uma licença para "continuar a servir quaisquer frades enfermos". A licença real era um documento valioso, porque a suspeita de barregania recaía frequentemente sobre as mulheres que serviam aos clérigos. A licença não era obrigatória, mas fornecia segurança a essas mulheres, pois thes permitia realizar o seu trabalho sem o risco de serem presas como barregãs. Percebe-se aqui que mesmo quando as mulheres eram insuspeitas cristãs, desejosas de fazerem a caridade, a convivência delas com sacerdotes era pouco recomendável, pois o gênero feminino estava potencialmente inclinado ao mal.

Com o estabelecimento da obrigatoriedade do celibato clerical, a Igreja preocupou-se em regulamentar as situações nas quais o direito canônico permitia que mulheres convivessem com clérigos. Na literatura eclesiástica, a presença feminina no cotidiano dos sacerdotes era vista como um perigo que os expunha às tentações. Nas vidas de santos é comum o protagonista aparecer constantemente ameaçado por "ataques" de mulheres, aos quais devia obrigatoriamente resistir de forma heróica. Em uma das hagiografias de São Bernardo, o santo é atacado em sua cama, durante a noite, por uma moça nua que tenta, inutilmente, seduzi-lo. No mesmo relato, São Bernardo é tentado pela dona da casa em que estava hospedado. Para se 
"Quem chegar por último émulher do padre"

livrar do assédio, o santo precisou lutar com todas as suas forças, gritando e despertando a casa inteira (Duby, 2001:74).

Alguns livros de confissão destinados à instrução dos confessores orientavam os padres a não receber mulheres com "cabelos frisados, rostos pintados e rebocados, brincos e outros semelhantes ornamentos cheios de vaidade", e os ensinavam que a confissão de mulheres devia ser realizada em um espaço descoberto da Igreja e apenas durante o dia (Delumeau, 1993:329).

Por essas razões, as mulheres acompanhantes ou criadas de clérigos deviam ser indubitavelmente honestas, de idade avançada $e$, de preferência, não deviam coabitar com eles.

Outra barregã, de nome Maria Gonçalves, recebeu o perdão régio em 23 de dezembro de 1444, a pedido de D. Diogo Afonso Malheiro, pai de um menino que a condenada "criava ao peito" (Livro de Chancelaria de D. Afonso V, vol. 25, fl. 3). Maria Gonçalves vivia publicamente como concubina de um clérigo e o fato de ser nutriz indica que tinha um filho pequeno, cujo pai talvez fosse o clérigo.

No preâmbulo de sua Carta de Perdão, Malheiro, o requerente, comunicava a sua condição nobiliárquica de escudeiro e contador real, assinalando, portanto, que o enunciador era uma pessoa importante, um homem respeitável que merecia a atenção do monarca. As redes clientelares, que permitiam o acesso a pessoas influentes no Reino ou próximas ao rei, eram frequentemente acionadas pelo acusado ou condenado nas Cartas de Perdão: "um dos modos que mais produz o efeito desejado é começar uma súplica inserindo o acusado nas redes familiares, sociais e profissionais do seu tempo" (Duarte, 1993:45).

Malheiro narrou a história de Maria Gonçalves de maneira comovente. O leite da ama do seu filho pequeno secara. A única mulher habilitada para cuidar do bebê era "a manceba de um prior da vila". Ela estava encarregada da amamentação do menino quando chegou à vila o corregedor da comarca, Afonso Gil, que mandou prendê-la. Posteriormente, Maria Gonçalves foi degredada da vila e do seu termo. 
É relevante atentar para o fato de que a prisão da barregã somente foi efetuada quando um oficial régio chegou à vila. $\mathrm{O}$ requerente informava na Carta de Perdão que a situação de barregania clerical era pública. Todavia, não houve denúncia popular. Se uma parte da população condenava a barregania clerical e esperava que o poder régio a combatesse, por outro lado, muitos sacerdotes mantinham barregãs às vistas de todos, trazendo-as tão bem $e$ melhor vestidas $e$ guarnecidas que as mulheres de leigos; e muitas mulheres virgens deixavam de tomar maridos legítimos e de viver em conformidade com as regras que Deus estabelecera no mundo para se juntarem à clérigos em pecado mortal (Ordenações Afonsinas, título XIX, artigo 1:58-59).

As Cartas de Perdão, como a que Malheiro escreveu para defender Maria Gonçalves, são textos que permitem compreender os hábitos da vida cotidiana $e$ os valores em confronto na sociedade medieval portuguesa. Na narrativa de Malheiro, aparece uma personagem que desempenhava uma atividade relevante nas relações familiares da Idade Média: a nutriz mercenária. No medievo, as mulheres geralmente tinham um número elevado de filhos. O intervalo decorrido entre $\mathrm{o}$ nascimento das crianças era curto. A tradição médica aconselhava que uma mulher que amamentava não devia manter relações sexuais. Do contrário, o leite estragaria. Algumas mães, sobretudo as de condição abastada, enviavam os filhos pequenos para amas de leite, para poderem reiniciar as atividades sexuais e, assim, "segurar" os seus maridos. Havia um verdadeiro comércio do aleitamento. Mulheres pobres tornavam-se nutrizes, transformando a amamentação em um meio de subsistência (Flandrin, 1988:161279).

Tal interdição sexual das mães "honradas" durante a amamentação revela o caráter profundamente misógino de como o corpo feminino era representado. Aqui se percebe que os papéis da mãe e da mulher sexualmente ativa eram segregados como se a abstinência estivesse naturalmente associada à qualidade do 
"Quem chegar por último émulher do padre"

leite e à saúde do bebê. Entretanto, outra questão era a necessidade de agradar os maridos uma vez que

para as mulheres das classes altas essa prática de contratar uma ama-de-leite se inseria claramente nos valores sociais dominantes da época: a prioridade dada aos interesses masculinos (inclusive sexuais) (Sandre-Pereira, 2003:472).

No depoimento em defesa de Maria Gonçalves, Malheiro demonstrou a preocupação de um pai com a saúde $e$ a vida de seu filho. Afirmava o seu temor de ficar "sem ter quem amamente o menino [que] poderá morrer ou [... sofrer] alguma enfermidade". Assim, solicitava ao rei que perdoasse a acusada para que o rebento não "perecesse a míngua de não ter quem lhe criasse". O relato informava que a criança era do sexo masculino: um herdeiro, portanto. Quando se utiliza o sexo da criança numa Carta de Perdão como elemento de convencimento, isso revela o caráter misógino da sociedade medieva, na qual os filhos varões eram exaltados $e$ as crianças mulheres rejeitadas e até vistas como mau augúrio.

A ausência de argumentos que fizessem referências sobre barregãs que amamentavam crianças mulheres pode esclarecer sobre as estratégias de apelação e convencimento da época. $\mathrm{O}$ fato de a barregã ser ama de leite poderia ser um atenuante, desde que a criança fosse um menino. Caso fosse uma menina talvez a justificativa pudesse ser desqualificada ou mesmo inválida, uma vez que tratava-se do julgamento de um crime tipicamente feminino. Segundo Eni Orlandi (1997:12),

o silenciamento (que já não é silêncio, mas "por em silêncio") nos mostra que há um processo de produção de sentidos silenciados que nos faz entender uma dimensão do não-dito absolutamente distinta do que se tem estudado sob a rubrica do "implícito". 
O perdão foi conferido a Maria Gonçalves sob a recomendação de que ela deveria adotar uma vida honesta, casando-se legitimamente ou entrando em uma ordem religiosa.

Outro caso investigado foi o de Leonor Fernandes, moradora de Alcácer, que em 25 de fevereiro de 1450 recebeu o perdão real. Em sua Carta, ela registrou que o meirinho a prendera em sua casa, sob a acusação de que ela era "manceba de um clérigo" (Livro de Chancelaria de D. Afonso V, vol. 34, fl. 149v). Leonor contestava a acusação do oficial régio e assegurava que "vivia só" e não fora encontrada na residência de um clérigo, tampouco na companhia de um clérigo em qualquer outro lugar. Pedia ao rei que lhe perdoasse a pena de degredo, sob a alegação de que era uma "mulher pobre e minguada", incapaz de se "manter em terra alheia", que desejava apenas se "casar ou viver sozinha honestamente".

Muitas barregãs eram descritas, nos relatos das Cartas de Perdão, como pessoas humildes e ignorantes, atributos utilizados para torná-las mais dignas de piedade. A doença também era um recurso muito empregado, com adjetivações do tipo: "pobre viúva incapacitada" (Davis, 2001:34).

Em todas as histórias de barregãs de clérigos narradas nas Cartas de Perdão, a prisão das acusadas ocorreu após denúncia feita a oficiais régios (Ordenações Afonsinas, livro V, título XIX, artigo 9:63). A preocupação política de punir como crimes certas práticas da intimidade converteu a delação como o principal instrumento de incriminação dos suspeitos de delitos sexuais, dado a dificuldade de se reunir indícios para provar a ocorrência de tais atividades pecaminosas.

Se a sexualidade é um conhecido tabu da sociedade medieval, constituída por imaginário que exaltava a abstinência e a castidade, a sexualidade feminina era vista quase como uma aberração maligna, especialmente por estar associada à feitiçaria. O compêndio medieval Malleus Maleficarum (1484), por exemplo, é um verdadeiro tratado misógino que alerta os sacerdotes e leigos sobre os ardis demoníacos da mulher: "Toda bruxaria tem origem 
"Quem chegar por último émulher do padre"

na cobiça carnal, insaciável nas mulheres" (Kremer; Sprenger 1991:121), portanto era "maior o contingente de mulheres que se entregam a essa prática, inclusive as predispondo à cópula com o demônio, com os Íncubos" (id.ib.:84). As perversões sexuais masculinas seriam exceções "porque sendo intelectualmente mais fortes que as mulheres, são mais capazes de abominar tais atos" (id.ib.:332).

O longo processo de demonização da mulher em parte tem suas origens na resignificação dos cultos relacionados à Grande Mãe e às deidades femininas, difundidos em diversas sociedades tradicionais da Antiguidade. A associação da imagem mulher aos ciclos da natureza e à terra, como aquela que gera a vida e depois a consome (sepulta) foi totalmente distorcida e temida com o advento do cristianismo.

Essa ambiguidade fundamental da mulher que dá a vida $e$ anuncia a morte foi sentida ao longo dos séculos, $e$ especialmente expressa pelo culto das deusas-mães. A terra é o ventre nutridor, mas também o reino dos mortos, sob o solo ou na água profunda. É o cálice da vida e da morte... (Delumeau, 1993:312).

Em termos psicanalíticos, o controle da sexualidade feminina exigido pela Igreja está relacionado com o poder de autonomia do sujeito, sua criatividade e a transgressão. Os aspectos da libido feminina foram diretamente associados a fatores instintivos, mundanos e caóticos. Segundo H. Bloch (1995:17), os primeiros padres da Igreja consolidaram a ideia de feminização da carne, "ou seja, de acordo com a metáfora da mente e do corpo, a associação do homem com mens ou ratio e da mulher com o corporal". Zordan (2003:337-338) assinala que na sociedade medieva havia um grande temor inconsciente relacionado à voracidade do prazer feminino, inextinguível por estar desvinculado dos limites fisiológicos da ereção fálica: 
Como fator chave na diabolização da mulher, a sexualidade feminina apresenta-se sempre acompanhada de insaciedade, produzindo-se, assim, a imagem da bruxa voraz, a ogra devoradora que engole todos os seus filhos. Talvez como subproduto da miséria, sua fúria é o resultado de um imenso apetite impossível de ser satisfeito. Essa fome é intensificada no sexual e vem impressa no mito da avidez vaginal, sendo a boca da vulva considerada como a parte mais insaciável da mulher. Seus aspectos noturnos, funestos e lunares afastam-na das racionalidades.

Enfim, a barregania clerical foi duramente perseguida por atentar contra dois pilares importantes do patriarcado cristão, a saber, o sacerdócio casto e o matrimônio. As Cartas de Perdão conservam dados preciosos que revelam as relações de gênero do medievo português, por caracterizarem a tentativa de assujeitamento/conformidade da mulher às regras de conduta determinadas pela Coroa e pela Igreja.

Ao final da Idade Média, sentidos depreciativos atribuídos a barregãs de religiosos permanecem. Davis atestou a recorrência das expressões "mulher do padre" e "mulher do frade" em Cartas de Perdão francesas do século XVI. Nesse período, mulher do padre e mulher do frade eram formas de insulto muito comuns, que situavam uma mulher, independentemente do fato de ela ser concubina de um clérigo, em uma condição próxima ou pior que à da prostituta.

Uma Carta de Perdão relatava a história da vendedora Agnès, que fora agredida, quando estava no mercado "comercializando pão respeitosamente", por um homem que a xingara de "puta suja, mulher de padre, mulher de frade". Outra Carta relatava uma discussão entre duas mulheres, em que uma ofendera a outra como "puta, saco de sacanagem, mulher de padre" (Davis, 2001:144).

O estigma da mulher de padre associada a representações da prostituta e da adúltera - enquanto modelos de conduta imoral e maligna - tem relação com o temor atávico do feminino, da 
"Quem chegar por último émulher do padre"

sexualidade transgressora e da necessidade da instauração de uma pedagogia do terror implementada pela ortodoxia cristã patriarcal com o intuito de culpabilizar as mulheres pelas mazelas do mundo. Norbert Elias e Scotson (2000) lembram que existem certos mecanismos que reforçam a inferiorização de um grupo pelo outro. Para haver a dominação, o grupo estabelecido (no caso, o binômio Igreja-Estado e seus preceitos patriarcais) necessita estigmatizar o grupo que deseja excluir/submeter. Tais clivagens hierárquicas também se reproduzem dentro de grupos subalternos fazendo com que a mulher, que já é considerada inferior no medievo, seja ainda mais estigmatizada quando exerce sua sexualidade fora do casamento (adúltera/prostituta) e quando seu parceiro é um clérigo. Seguindo essa lógica, pode-se inferir que na sociedade medieval a concubina de clérigo era considerada mais desprezível que a prostituta comum por ter desvirtuado um homem santo, um sacerdote, daí a necessidade de severa punição.

(...) a peça fundamental da configuração estabelecidosoutsiders é um equilíbrio instável de poder, com as tensões que lhe são inerentes. Essa é também pré-condição decisiva de qualquer estigmatização eficaz de um grupo outsider por um grupo estabelecido. Um grupo só pode estigmatizar outro com eficácia, quando está bem instalado em posição de poder dos quais o grupo estigmatizado é excluído (id.ib.:23)

Atualmente, para além do significado de barregã como concubina, existem outros que foram construídos pela sociedade medieval lusa e que continuaram atuantes ao longo de séculos: mulher de vida dissoluta, mulher devassa, pervertida, rameira. Embora hoje a Igreja e o Estado estejam impedidos de punir legalmente as concubinas de clérigos, o discurso machista/sexista, advindo da antiga condenação de tais práticas, ainda é reproduzido no cotidiano das relações entre os sujeitos, atualizando as imagens depreciativas sobre as mulheres de padre. 
Na esfera do cotidiano, elas continuam sofrendo o estigma desta condição.

Uma memória cultural antiquíssima preservou a representação da condição infame das mulheres de clérigos. No Brasil, ainda hoje meninos e meninas divertem-se em brincadeiras infantis em que o/a perdedor/a é associado à condição negativa da antiga barregã de clérigo. As crianças desconhecem a tradição que construiu o sentido do enunciado "quem chegar por último é mulher do padre", mas sabem que ser mulher do padre é uma situação desfavorável e indesejada.

$\mathrm{Na}$ definição dos dicionários de língua portuguesa, o termo "mula sem cabeça" significa metaforicamente a "amante de padre, que segundo a crendice popular, transformada em mula sai, em certas noites, a cumprir seu fado" (Fernandes; Luft; Guimarães, 1998:420). Em lendas contadas em diferentes regiões do Brasil, as mulheres de padres circulam pelas noites como criaturas amaldiçoadas que aterrorizam as pessoas: mulas-sem-cabeça que vagueiam arrastando correntes presas às patas.

Do fatigante percurso dessas suas periódicas peregrinações noturnas, a mula, no outro dia, já tornada ao seu natural estado feminino mostra sinais no seu corpo, produzidos pelas correntes que arrastara quando vagava pelas longínquas paragens. Esse seu "tristíssimo fadário" faz parte da sua penitencia pelo seu pecaminoso viver. Já o padre, para purificar-se dos seus pecados, devia amaldiçoar a barregã no ato da celebração da missa, antes de tocar na hóstia para a consagrar (Costa, 1974:42).

As histórias de Beatriz Gonçalves, de Leonor Domingues, das duas Marias Gonçalves e de Leonor Fernandes - as personagens das Cartas de Perdão analisadas - exemplificam o imaginário que construiu, no terreno do cotidiano, a condição maldita dessas mulheres vistas como mundanas e pecadoras. As barregãs de clérigos foram assim representadas porque o seu modo de vida estava afastado dos padrões de condutas das 
"Quem chegar por último émulher do padre"

mulheres honestas. Elas mantinham relações conjugais torpes $e$ desprezíveis, portanto deviam ser punidas, silenciadas $e$ marginalizadas para salvaguardar o projeto de purificação $e$ ordenamento da cristandade, calcado nos estatutos do sacerdócio e do matrimônio.

\section{Referências bibliográficas}

AlmeidA, Fortunato de. História da Igreja em Portugal, vol. 1, 2 e 3. Porto, Portucalense, 1967.

BLOCH, R. Howard. Misoginia Medieval e a invenção do amor romântico ocidental. Rio de Janeiro, Ed. 34, 1995.

CHARTIER, Roger. A História hoje: dúvidas, desafios, propostas. Estudos Históricos, vol. 7, n 13, Rio de Janeiro, 1994, pp.97-113.

. Diferença entre os sexos e dominação simbólica. Cadernos Pagu (4), Campinas-SP, Núcleo de Estudos de Gênero Pagu/Unicamp, 1995, pp.37-47.

COSTA, Pereira da. Folclore pernambucano: subsídios para a história da poesia popular em Pernambuco. Recife, Arquivo Público Estadual, 1974.

DALARUM, Jacques. Olhares de clérigos. In: KLAPISCH-LUBER, Christiane. (org.) História das mulheres no ocidente: a Idade Média. Porto, Afrontamento, 1993.faltam as páginas

DAVIS, Natalie Zemon. Histórias de perdão e seus narradores na França do século XVI. São Paulo, Companhia das Letras, 2001.

Delumeau, Jean. História do medo no Ocidente: 1300-1800 - uma cidade sitiada. São Paulo, Companhia das Letras, 1993.

DuARTE, Luís Miguel. Degredados: justiça e criminalidade no Portugal medievo. Tese de Doutorado em História, vol. 1, Universidade do Porto, Porto, 1993.

DuBY, Georges. Eva e os padres: damas do século XII. São Paulo, Companhia das Letras, 2001. 
ELIAS, Norbert; SCOTSON, John L. Os estabelecidos e os outsiders: sociologia das relações de poder a partir de uma pequena comunidade. Rio de Janeiro, Jorge Zahar, 2000.

Fernandes, Francisco; LuFt, Celso Pedro; GuimarãEs, E. Marques. Dicionário Brasileiro Globo. São Paulo, Globo, 1998.

FLANDRIN, Jean-Louis. O sexo no Ocidente: evolução das atitudes e dos comportamentos. São Paulo, Brasiliense, 1988.

HeSPANHA, António Manuel. A punição e a graça. In: MATTOSO, José. (dir.) História de Portugal vol. 4. Lisboa, Estampa, 1992.

KRAMER, Heinrich e SPRENGER, James. Malleus Maleficarum O martelo das feiticeiras. Rio de Janeiro, Rosa dos Tempos, 1991.

LARAIA, Roque de Barros. Jardim do Éden revisitado. Revista de Antropológica, vol. 40, n ${ }^{\circ}$. São Paulo, USP, 1997, pp.149-164.

LE Goff, Jacques. Para um novo conceito de Idade Média: tempo, trabalho e cultura no Ocidente. Lisboa, Estampa, 1979.

Maleval, Maria do Amparo Tavares. As mulheres são o diabo. Rio de Janeiro, EDUERJ, 2004.

NAsCimento, Maria Filomena Dias. Ser mulher na Idade Média. Textos de história, vol. 5, n 1 . Brasília, 1997, pp.82-91.

ORLANDI, Eni. As formas do silêncio: no movimento dos sentidos. Campinas, Ed. Unicamp, 1997.

PITILlO, Silvana Assis Freitas. A personagem vicentina: uma representação do Portugal dos Quinhentos. Dissertação de mestrado em História, Universidade Federal de Uberlândia, 2002 [http://www1.capes.gov.br/teses/pt/2002 mest ufu_silvana assis freit as pitilo.pdf -acessado em 23/03/2009].

RossiAUD, Jacques. A prostituição na Idade Média. Rio de Janeiro, Paz e Terra, 1991.

SANDRE-PEREIRA, Gilza. Amamentação e sexualidade. Revista de Estudos Feministas 11(2), Florianópolis, julho-dezembro/2003, pp.467-491. 
"Quem chegar por último émulher do padre"

ScotT, Joan W. Prefácio a Gender and Politics of History. Cadernos Pagu (3), Campinas-SP, Núcleo de Estudos de Gênero Pagu/Unicamp, 1994, pp.11-27.

ZoRDAN, Paola. Bruxas: figuras de poder. Revista Estudos Feministas, vol. 13, n 2, Florianópolis, mai-ago 2005, pp.331-341.

\section{Fontes}

Aquino, São Tomás de. Suma Teológica. Vol. 2. Porto Alegre/Caxias do Sul, Escola Superior de Teologia. São Lourenço Brindes, Sulinas, 1980.

BÍBLIA. Português. Bíblia de Jerusalém. São Paulo, Paulus, 1995.

Livro de Chancelaria de D. Duarte. Lisboa, Arquivo da Torre do Tombo, vol. 3, fl.19v.

Livro de Chancelaria de D. Afonso V. Lisboa, Arquivo da Torre do Tombo, vol. 27, fl.101.

Livro de Chancelaria de D. Afonso V. Lisboa, Arquivo da Torre do Tombo, vol. 24, fl.35v-36.

Liuro de Chancelaria de D. Afonso V. Lisboa, Arquivo da Torre do Tombo, vol. 25, fl.3.

Livro de Chancelaria de D. Afonso V. Lisboa, Arquivo da Torre do Tombo, vol. 34, fl.149v.

ORDENAÇOES AFONSINAS. Lisboa, Fundação Calouste Gulbenkian, 5 v 1986. [Reprodução fac-símile da edição da Real Imprensa da Universidade de Coimbra, de 1792] 